\title{
Between Self and Spirit: Mapping the Geographies of Black Women's Spirituality
}

\author{
Carol E. Henderson \\ Office of Diversity, Equity, and Inclusion, Emory University, Emory, GA 30322, USA; \\ carol.e.henderson@emory.edu
}

Received: 26 October 2020; Accepted: 11 November 2020; Published: 20 November 2020

\begin{abstract}
"There wasn't enough for Indigo in the world she'd been born to, so she made up what she needed."
-Ntozake Shange

sassafrass, cypress, and indigo

"... the Spirit, or spirituality, defies definition-a fact that speaks to its power as much as it reflects its mystery."

-Gloria Wade-Gayles

My Soul is a Witness
\end{abstract}

I love the character of Indigo. She has to be one of the most unique female child characters in African American literature. A child of few words, Indigo creates her own world because "there wasn't enough for Indigo in the world she'd been born to" (Shange 1982). She is shaped by author Ntozake Shange as a girl-child who had a "moon in her mouth". Wise beyond her years, complex in spirit, Indigo embodies folk and ancestral culture, a spiritual reorientation of Black feminine consciousness personified in the many dolls that become her community of witnesses, her vocal expressions of defiance, protection, agency, and empowerment when the world seemed too big for her, and words were not adequate enough to speak into existence that which she needed. Made of and filled with cotton root bark, comfrey leaves, and dried sunflowers, Indigo's dolls-Jamaican, Caribbean, and American - weave past and present into a creative interrogation of the intertextualities of collective African identities. Shange's critical intervention-a practice that, at once reaffirms and yet destabilizes ineffectual discourses that efface resistive narratological frameworks in Black women's literatures-resituates divine Black feminine consciousness in a literary methodology that moves the margins to the center. Shange's text calls into question the ways Black women's bodies become written texts-marked by racism, sexism, colorism, and otherism. Yet they are spiritual beings, nonetheless. Shange's novel utilizes creativity-weavers, dancers, midwives-as symbolic linkages of culture, community, and history. And just as Indigo's spiritual offerings become her four-foot tall dolls whose arms she crawls into to find soul comfort, Shange develops another "Creation story" where Black women become the center of her universe and recipes, rituals, dream stories, and letters the beatitudinal moorings that anchor Gullah/Geechee mores at the center of her narrative.

This special collection seeks to explore the ways in which writers reclaim the Black female body in African American literature using the theoretical, social, cultural, and religious frameworks of spirituality and religion. In order to more fully consider the ways Black women have spiritually represented themselves and their bodies in African American literature, one must consider, as Katherine Clay Bassard reminds us, a variety of religious traditions that shape their religious experiences, including Christianity, Islam, African and neo-African traditional, among others (Bassard 1999). This practice of interpreting Black women's intertextuality (what Bassard terms spiritual interrogation) structures visions of reading that provide a richer understanding of the ways in which the sacred and secular, the spiritual 
and political, become a lens through which to see African American female subjectivity in all of its nuanced complexity. This collection critically engages these ways of knowing as it simultaneously enters into conversation with other collections who have done this work in notable fashion (Henderson 2014; Hopkins and Pinn 2004; Weir-Soley 2009; West 2012). Of key importance to this current collection is Black women's agency within these realms-acknowledged and affirmed in prose, poetry, essays, speeches, written plays, or short stories. Whether it is Indigo (sassafrass, cypress, and indigo) creating a world with her dolls that shepherds her through her rite of passage to womanhood, or Baby Suggs declaring in her "fixing ceremonies" in the Clearing that "in this here place, we flesh" (Morrison 1988), authors have sought to discuss the tensions of the sacred and secular through concepts such as forgiveness, redemption, passion, alienation, motherhood, sex, marriage, just to name a few.

In "Are You Sure, Sweetheart, That you Want to Be Well?" Belinda Waller-Peterson considers mental illness, the journey to wholeness, and its ties to Black women's spirituality in Toni Cade Bambara's The Salt Eaters. Navigating the complex realities of a mental health crisis which manifests itself in an attempted suicide, Salt Eaters' central character, Velma, finds her life on the edge of a figurative cliff. Spiritual isolation, the tensions of physical/psychic/emotional vulnerability, and the physical loss of a baby exacerbate this body in pain. Velma's sojourn to mental wellness, as Waller-Peterson argues, then becomes an interactive process that involves community, a spiritual guide, Minnie, and womb-like healing spaces/places informed by spiritual and cultural modes of knowing that hold the essence of ancestral alternative healing practices. Minnie, in particular, accesses these healing rituals through psychic and physical touch, "stepping into the body to listen to it to bring the body/patient in alignment [through] the use of touch, hearing, voice, music to expose its [the body's] abnormalities". Minnie's question to Velma, "Are you sure, sweetheart, that you want to be well?" recognizes self-creation and one's own agency in actualizing a path to wellness-a liberatory and political act of resistance, as bell hooks has said elsewhere (hooks 1989). Central to Waller-Peterson's discussion is the collective healing that allows others the permission to heal themselves. These community witnesses, many of them wounded storytellers themselves, join Velma in a communal act of affirmation that embraces an inheritance of love and self-care rooted in truth-telling.

Keith Byerman, in "Talking Back: Phillis Wheatly, Race, and Religion", re-engages the import of Wheatley's work in the moral conversation of evangelical Christianity in her 1773 collection Poems of Various Subjects, Religious and Moral. As Byerman reminds us, much has been written on Wheatley's interplays with the future Thomas Jefferson. In Notes on the State of Virginia (1785), Jefferson questions the veracity of Wheatley's work -its intellectual depth, its dignity, its composition. Wheatley's counterarguments to Jefferson's inhumane rhetorics situate themselves not only in the ways she manages her inquisition by the elite of white society, but also in the technical framings of her portrait and the religious threads interwoven into her literary works. Her portrait, meditative and pensive, dignified and regal, positions the Black female body in what Maurice Wallace and Shawn Michelle Smith (Wallace and Smith 2012) call "the making of African American Identity". Pictorial image-making then becomes a way to shift visual literacy in ways that establish the material utility of the written (book of poetry) and the embodied text. By connecting the experiences of people of African heritage to the biblical stories of bondage and freedom, grief and mourning, redemption and spiritual enlightenment to, as Byerman concludes, "take on the giants", Wheatley "gains some control over the representation of herself and her race".

In "Looking Foreword to Milton in Toni Morrison's Paradise", Reginald Wilburn traces the intertextual threads of Miltonic influences that find resonance in Morrison's novel Paradise. According to Wilburn, Morrison converts Milton into "tropological vernacular" through her revisionist interplay of Milton's Paradise Lost. Starting with Milton's conceptualization of the concepts of paradise, heaven, hell, and what it means to be a "fallen woman", Morrison extends the critical lens of these discussions to perform a spiritual interrogation of Milton's narrative that reclaims Eve's pre-eminence as the first mother of humankind. Within the terrain of other spiritual and religious expressions-tenets Morrison puts in conversation with Christian theology and its religious practices-Morrison complicates the Eve 
aesthetic, creating pathways that nestle Eve's progenic lineage in the textures of a Black womanist ideology. More than just racializing Eve, Morrison extends the "many faces of Eve" moniker to trouble the sublime and disrupt the customary twinning rudiments of good/evil, black/white, male/female. In Paradise, Eve becomes several women in the Convent whose very presence disrupts male authority in the all Black town of Ruby. The brutality enacted upon the women in the Convent serves as a way to "reassert a particular order", explains Wilburn, a way to control "wicked bodies" deemed "antithetical to conventions of true womanhood". Much as Milton's pen sought to do violence to Eve by minimizing her presence in Paradise Lost, Morrison's recovery project includes not only restoring the humanity of the women in the Convent, but also "rupturing racial language as an emancipating discourse of freedom", in Wilburn's estimation. The divine is symbolized in the gifts each woman possesses as the lives they live become the sermons they preach. This is the power of Morrison's Paradise. In gaining a greater understanding of themselves, the women in the Convent allow the reader to reimagine the translatory tenets of redemption, restoration, and spiritual intimacy-not as weapons of perversion or exclusion, but as mechanisms for a resurrection of a different sort. In this space, paradise is reimagined in the here and now as the spirit takes flight, surrounded by a cloud of witnesses who lose the binds of captivity to teach a different liberation gospel.

In "Spiritual Eroticism and Real Good Loving in Tina McElroy Ansa's The Hand I Fan With", Georgene Bess Montgomery lays bare the complex relationship Black women have had with the church. Caught between the polar binaries of virgin and whore, Black women have had to "internalize the shame of sex and uphold the mantle of chasteness", according to Montgomery. Using her own personal narrative as a prologue to the discussion, Montgomery speaks in powerful terms about her Pentecostal upbringing "which informed her notions of a woman's place and the cost of embracing sexual pleasure". These themes are continued in her examinations of Black women's texts as varied as Harriet Jacobs' Incidents in the Life of A Slave Girl to Gloria Naylor's Women of Brewster Place. It is here, that Montgomery ascertains, Black women embrace their whole selves in an enjoyment of love, life, and sex, even if it means, as was the case with Alice Walker's Shug Avery, one is disowned by their religious family. Yet it is the attention that Montgomery directs to Ntozake Shange's sassafrass, cypress, and indigo that offers an alternative lens through which to see not only the Black woman's physical body-but the spiritual essence of that body. Grounding her interrogations of Black women's spirituality in African deities Shango, Oshun, Oya, and Elegua, Montgomery reveals Shange's alternative narrative that "where there is woman, there is magic". Because the traditional avenues of spiritual expression portend a spiritual woman that is pious, quiet, submissive, and pure-a godly woman also bound by the curse of Eve whose sinful desires in the Garden of Eden manifest themselves in her menstrual cycle-Shange counters this narrative through a ritual of rose petals, a wearing of a garland of flowers, and a blessing that embraces one's sensuality as an extension of beauty, love, and harmony. Montgomery's focus on African cosmology broadens evaluations of the Black woman's body and spirituality to include the ways in which Oshun as "deity of beauty and sensuality spiritualizes lovemaking". This spiritualization is not bound by religious parameters but is tied to the sensory elements of eroticism inhabitant in the flesh as a way that reclaims one's spiritual connection through joy and the pleasures of an intimate, orgasmic union of two people. Anchoring her discussion in Tina McElroy's The Hand I Fan With, Montgomery's focus on ghosts, cauls, familial legacies, and protagonist Lena's otherworld power reminds us that spiritual transformation, in McElroy's novel, is beautifully tied to loving one's complete self either through the act of lovemaking—or the sensual ecstasy of affirming one's spirit self and her gifts. It is here that the magic is found, and the heart, spirit, and the body sing.

In "Set Thine House in Order: Black Feminism and the Sermon as Sonic Art in The Amen Corner", Melanie R. Hill examines the figure of the Black preacher. Leading with W.E.B. DuBois's analysis in "Of the Faith of Our Fathers", Hill discusses how the performativity of the preacher "renders the Black body visible in a period where Black people and everything that characterized them were deemed invisible". It is in preaching The Word that moral authority is granted, and leadership and spiritual power become refigured in the prayers, songs, shouts, and dances that amplify spiritual freedom 
over oppression and captivity. What is important in Hill's discussion is the way the Black church has overwhelmingly figured the preacher as Black and male, and in the canonical scholarship of the early twentieth century, these characterizations have translated into an undervaluation of the Black woman preacher. Hill asserts that recentering the preacher as a Black woman would require a re-envisioning of the Black woman in religious discourse to more fully understand the experiential impact of her presence within the sacred agenda of the Black experience. James Baldwin's first play, The Amen Corner (1954), situates this discussion in the Civil Rights Movement, and the textures of Brown v. Board of Education I and II. According to Hill, at a time when the Black male preacher was synonymous with The Movement, Baldwin troubles that social view through his rendering of Margaret Alexander, the central figure in Amen Corner.

Maurice O. Wallace in "'Precious Lord': Black Mother-Loss and the Roots of Modern Gospel" returns the spiritual lens of interrogation to Thomas Dorsey's iconic 1932 gospel song Take My Hand, Precious Lord. Of key concern to Wallace is the spectral bodies of a Black mother and child (Dorsey's wife Nettie and child) that haunt the lyrics of this song. Dorsey's wife, Nettie, dies during childbirth, and two days later, their son dies as well. As Wallace sees it, "the larger history of black maternal and infant mortality" undergirds the grief expressed in this song. This grief is simultaneously rooted at the intersections of death, Black motherhood, and the racial politics of women's reproductive health care. Each becomes diminished "except that ... an alternative history of the modern gospel sound, one that helps African American religious and musical histories see and hear better what we might call, with the deepest debt to Emily Lordi, 'black feminist resonance' in early and late black musical production by black women and men." In short, if Dorsey has been seen as the father of gospel, we must also imagine his wife Nettie Dorsey as the unspoken mother of gospel, and her tragic journey at childbirth, a Black social mourning song of loss. Moreover, as Wallace contends, Precious Lord realizes "a black womanist structure of feeling, intensely and excessively sonified" in ways that hauntingly "gave new birth, mother and child, to black religious music". It is the visual spectacle of mother and child in a lace-laden casket, however, that provides an opportunity for communal witnessing and grieving that conjures up and re-presents, as Karla F.C. Holloway states elsewhere (Holloway 1997), a persistent lament for a departed body. These rituals make sure we do not forget-that we remember these narratives and the conditions surrounding their dying. What Wallace reminds us is that Precious Lord, in its own way, is a mooring place-a cultural memorial to the racial circumstances of Jim Crow that impacted Nettie Dorsey and Thomas Jr.'s dying. And although gospel and its remnants frame the rhythm of Precious Lord, it is the resonance of the cries sung in the somber notes of this iconic piece that ushers forth, as Wallace states, the "the mournful expressions of black women's spiritual consciousness".

In "Rewriting Race, Gender and Religion in Toni Morrison's Song of Solomon and Paradise", Heather Hathaway considers Morrison's creative process for establishing women as spiritual agents in her narrative. Acutely aware of the strictures of orthodox Christian systems, Morrison's womanist theology gestures towards a reframing of African American religious expression that not only shows Christianity's indelible mark on the lives of Black people, but also shows the ways they have reshaped its social orders to carve out a sort of postmodern spiritualism innately divine, political, and persuasive. Hathaway, in particular, points to Morrison's use of biblical language, irony, inversion, and revision, specifically in Song of Solomon and Paradise, to preach a principled way of being that lays bare the misogynistic underpinnings of orthodox Christianity. Instead, Morrison "offers female spiritual leaders, grounded in mercy, communal wholeness, and love" as surrogates for a womanist epistemology. Morrison's characters, Lena (short for the biblical Magdalene), First Corinthians, Hagar, Pilate, and Ruth become instructive tools to provide a kind of wisdom about belonging, affirmation, religiosity, and spiritual divinity. And, as Hathaway determines, Morrison's use of Gnosticism directs attention to this alternate spiritual belief that stresses the divine within each woman, her journey to redemption, self-knowledge, and self-forgiveness. Such explorations also reveal how one's spiritual sojourn leads to larger queries centered on one's quest for true citizenship, freedom, and identity. 
In “Christianity's Last Stand: Visions of Spirituality in Post-1970s African American Women's Literature", Trudier Harris charts the pivotal moments in African American literature where Black women authors begin to question the preeminence of Christianity as the only religious belief system in the African American experience. Using the relationship of Beneatha and Lena Younger in Lorraine Hansberry's Raisin in the Sun as a guide, Harris explains how Beneatha's questioning of the idea of God serves as a turning point-the last stand in African American literature-because "Mama Lena can force a recitation, but she cannot force belief" after she slaps her daughter across the face for saying "There simply is no blasted God-there is only man and it is he who makes miracles!" In one of the most iconic scenes in the play, Mama Lena makes Beneatha recite through tears, "In my mother's house there is still God." Hansberry's work was a precursor to the Black Arts Movement and the Black Aesthetic, whose reconceptualization of the spiritual is rooted in the mystical and transformative tenets of Africa and its belief systems. Forays into the work of Paule Marshall, Gloria Naylor, Ntozake Shange, Toni Cade Bambara, Octavia Butler, Jewelle Gomez, among other writers, emphasize the values that undergird these spiritual communities, the special bonds of relationship, and the noteworthy tools of the supernatural. The sway of immortality, the reliance on fields of writing-science fiction, speculative, and horror-allow these authors to stretch the dialogue of spirituality beyond the traditional. As Harris concludes, the very heavy presence of African American women in Black congregations, whose leadership does not reflect their diversity, portends a historical reckoning. "Overburdened black women in churches throughout the United States could learn a thing or two from their literary sisters," writes Harris. Indeed, African American literature offers an avenue to interrogate these restrictive patriarchal spaces.

In a poignant meditation on the lived narratives of early African American women, Elizabeth West reminds us in her essay, "Community and Naming: Lived Narratives of Early African American Women's Spirituality", that community is spirit, and it is this spirit that influences African American women's acts of self-actualizations accessed through group affinity and "a collective spiritual corpus". Bound by an African ethos that affirms one's humanity and soul, early Africans naming practices rested in Nommo, the divine power to create and recreate self through a process of unnaming and naming. These acts of self-agency presented themselves in the invention of names that embodied one's enslaved and freed histories and reveal themselves in the "epistemological and spiritual ethos that early Africans transported to their diasporic communities". These declarations of self-empowerment find remnants in the stories of Frederick Douglass and Sojourner Truth as West reiterates and are notably present in those individuals who choose African and Muslim names for themselves and their progeny. These practices are themselves "a narrative trail of their existence and their family's history", and encourage us to rethink that which is not just written but is unconventional within the narratological space. Using one of Alice Walker's underappreciated short stories, "Everyday Use", West recalls the spiritual threads that manifest themselves in quilt making, and how this cultural tradition is itself an archival tool whose artifactual creation records familial and communal histories and identities in the patches of the quilt itself-its interconnectedness binding the past to the present. In a similar fashion, West directs attention to the secular and sacred-the body and the spirit-in her examination of Beyoncé's Lemonade and Julie Dash's Daughters of the Dust. Building upon the critical work of Kinitra Brooks and Kameelah Martin, West draws linkages between Beyoncé's creative nod to Dash, and the multidimensional narratological tenets that tie Black women's spiritual recovery of womanist history to the intellectual paradigms of Black folk parables, music, and dance. These "generational beliefs, practices, and ways of knowing ... if pieced together or sampled, can breathe life into black women's muted narratives from generations past". Such an examination allows West to recover the narrative of Francis Sistrunk (b. 1822), a descendant in her own mother's genealogical line. Powerfully weaving archival records, the 1840 US census, and kinship networks, a fuller picture of West's family emerges as Sistrunk's children and her descendants "become living archives of her life". As West declares, "Francis Sistrunk was re-discoverable in the 21st century because she left defining markers in the pieces 
of her life". These pieces include Sistrunk's naming practices of her sons in her lineage that allow her to be the architect of her family's place in familial history.

\section{Some Concluding Remarks ${ }^{1}$}

When I was asked by Religions to serve as a guest editor to a Special Issue on Black women's bodies and spirituality, I was honored to accept the task. My body of work has continuously paid homage to Black women's creative gifts-their uncanny ability to invent and reinvent themselves in ways that make known their spiritual strivings-their complex existence within social and cultural spaces that frame them as both outsider and insider, unworthy and worthy, deviant and sacred, excess and minimal. In the world of religious and spiritual entanglements, these ties that bind become all the more tenuous. As Tamura Lomax asserts in Jezebel Unhinged, "I learned that the Black Church and black popular culture influence each other, especially in their omnipresent circulating discourse of black womanhood." Indeed, as she goes on to point out, "this discourse of 'truth' can be just as death dealing, anxiety inducing, and dehumanizing as white supremacist discourse on race" (Lomax 2018). The intent of this current collection is to demonstrate that angst, and to point out how Black women's narratives-whether physical, embodied, written, creatively strung together, danced, or sung-are themselves a testament to Black women's resilience as they answer the call to serve as witnesses-and participants-in the spiritual sojourn of Black people in this country.

That call extends, as well, into our current social moment of racial reckoning with the egregious violence directed at Black bodies—brutalized, suffocated, maimed, and surveillanced - in live and living color before our eyes. The murders of Breonna Taylor, George Floyd, Atatiana Jefferson, Rayshard Brooks, Botham Jean, Ahmaud Arbrey, and countless others too numerous to name here, have made it excruciatingly clear how some value Black people in this country. This unconscionable realization, intertwined with a global pandemic that adversely impacts African American, Native, Indigenous, and Latinx communities in disproportionate numbers, amplifying the inequities and injustices prevalent in health care systems, social services, employment, and housing, grieves our souls, wounds our spirits, and invades our mental and spiritual wellness. It would seem odd to close this collection without acknowledging that. And so I do. I pay homage to Jesmyn Ward, who in her beautifully haunting eulogy to her beloved husband, and the father of her children, makes palpable the pain and grief of witnessing - the textures of its trauma and its respair (Ward 2020). I make room for her tears here... her revelations ... her healing $\ldots$ and ours.

Funding: This research received no external funding.

Conflicts of Interest: The author declares no conflict of interest.

\section{References}

Bassard, Katherine Clay. 1999. Spiritual Interrogations: Culture, Gender, and Community in Early African American Women's Writing. Princeton: Princeton University Press.

Henderson, Mae. 2014. Speaking in Tongues and Dancing Diaspora: Black Women Writing and Performing. New York: Oxford Press.

Holloway, Karla F. C. 1997. Cultural Narratives Passed On: African American Mourning Stories. College English 59: 32-40. [CrossRef]

hooks, bell. 1989. Talking Back: Thinking Feminist, Thinking Black. Boston: South End Press.

1 I am extremely grateful to the scholars who contributed essays to this special collection. Their wisdom, critical insight, astute analyses, and gracious collegiality made this collection all that it is. The numerous scholars who served as readers to these essays are essential contributors to this current work. Their generosity is gratefully acknowledged here. As well, I would like to thank the wonderful editorial staff at Religions who have been invaluable in seeing this project to its end. Your guidance through every step of the process was a breath of fresh air. Thank you for believing in us and the import of this current work. 
Hopkins, Dwight N., and Anthony B. Pinn. 2004. Loving the Body: Black Religious Studies and the Erotic. New York: Palgrave MacMillan.

Lomax, Tamura. 2018. Jezebel Unhinged: Loosing the Black Female Body in Religion and Culture. Durham: Duke University Press.

Morrison, Toni. 1988. Beloved. New York: Penguin Books.

Shange, Ntozake. 1982. Sassafrass, Cypress, and Indigo. New York: St. Martin's Press.

Wallace, Maurice, and Shawn Michelle Smith. 2012. Pictures and Progress: Early Photography and the Making of African American Identity. Durham: Duke University Press.

Ward, Jesmyn. 2020. On Witness and Respair: A Personal Tragedy Followed by Pandemic. In Vanity Fair's Special Issue: The Great Fire. Edited by Ta-Nehisi Coates. New York: Condè Nast.

Weir-Soley, Donna. 2009. Eroticism, Spirituality and Resistance in Black Women's Writing. Gainesville: University Press of Florida.

West, Elizabeth. 2012. African Spirituality in Black Women's Fiction: Threaded Visions of Memory, Community, Nature, and Being. Lanham: Lexington Books.

Publisher's Note: MDPI stays neutral with regard to jurisdictional claims in published maps and institutional affiliations.

(C) 2020 by the author. Licensee MDPI, Basel, Switzerland. This article is an open access article distributed under the terms and conditions of the Creative Commons Attribution (CC BY) license (http://creativecommons.org/licenses/by/4.0/). 